\title{
Gut content analysis of Lake Michigan waterbirds in years with avian botulism type $E$ mortality, 2010-2012
}

David A. Essian ${ }^{\mathrm{a}, 1^{*}}$, Jennifer G. Chipault ${ }^{\mathrm{b}}$, Brenda Moraska Lafrancois ${ }^{\mathrm{c}}$, Jill B. K. Leonard ${ }^{\mathrm{a}}$

${ }^{a}$ Northern Michigan University Biology Department, 1401 Presque Isle Avenue, Marquette, MI 49855, USA,

${ }^{\mathrm{b}}$ US Geological Survey, National Wildlife Health Center, 6006 Schroeder Road, Madison, WI 53711, USA

${ }^{\mathrm{c}}$ National Park Service, 2800 Lake Shore Drive East, Ashland, WI 54806, USA

*Corresponding author: * email: jileonar@nmu.edu, tel.: +1 906227 1619, fax: +1 9062271063

${ }^{1}$ Present address: Florida Atlantic University Department of Biological Sciences, 777 Glades Road, Boca Raton, FL 33431, USA, email: daessian@fau.edu 


\begin{abstract}
Waterbird die-offs caused by Clostridium botulinum neurotoxin type E (BoNT/E) have occurred sporadically in the Great Lakes since the late 1960s, with a recent pulse starting in the late 1990s. In recent die-offs, round gobies (Neogobius melanostomus) have been implicated as vectors for the transfer of BoNT/E to fish-eating birds due to the round goby invasion history and their importance as prey. Dreissenid mussels (Dreissena spp.) are also potentially involved in BoNT/E transmission to birds and round gobies. We examined gut contents of waterbirds collected in Lake Michigan during die-offs in 2010 - 2012, and the gut contents of culled, presumably BoNT/E-free double-crested cormorants (Phalacrocorax auritus). Round gobies were found in $86 \%$ of the BoNT/E-positive individuals, $84 \%$ of the BoNT/E-negative birds, and 94\% of the BoNT/E-free cormorants examined. Double-crested cormorants, ring-billed gulls (Larus delewarensis), and common loons (Gavia immer) consumed larger-sized round gobies than horned and red-necked grebes (Podiceps auritus and P. grisegena), white-winged scoters (Melanitta deglandi), and long-tailed ducks (Clangula hymealis). Other common prey included dreissenid mussels, terrestrial insects, and alewives (Alosa pseudoharengus). Our data emphasize the importance of round gobies and mussels in diets of Lake Michigan waterbirds and suggest they may play a role in the transfer of BoNT/E to waterbirds; however, round gobies and mussels were found in BoNT/E-positive, -negative, and -free individuals, suggesting that other factors, such as alternative trophic pathways for toxin transfer, bird migratory timing and feeding locations, prey behavior, and individual physiological differences across birds, may affect the likelihood that a bird will succumb to BoNT/E intoxication.
\end{abstract}

\title{
Keywords
}

Round goby, Dreissena, Clostridium botulinum, Piscivorous birds, Size class distribution. 


\section{Introduction}

Wild birds acquire Clostridium botulinum neurotoxin (BoNT) by ingesting contaminated prey (Reed and Rocke, 1992; Smith and Sugiyama, 1988). Avian botulism type C outbreaks can result in the death of large numbers of dabbling ducks and shorebirds on warm, shallow bodies of water (Newman et al., 2007). Botulism type C outbreaks have been attributed, in part, to a carcass-maggot feedback cycle, in which birds consumed contaminated invertebrates, such as maggots, from decaying carcasses. The feedback cycle exists because contaminated birds succumb to the toxin, and their carcasses provide new substrate for BoNT/C and maggots (Reed and Rocke, 1992). In contrast, botulism type E outbreaks in the Laurentian Great Lakes generally affect waterbirds that consume live fish and benthic aquatic macroinvertebrates. The food web pathways that maintain this cycle are not yet well characterized, making management of botulism type E outbreaks challenging.

Clostridium botulinum spores naturally occur throughout freshwater and marine sediments, and on plant and animal tissues which can act as reservoirs for C. botulinum spores (Espelund and Klaveness, 2014). When specific environmental conditions occur (including high concentrations of $C$. botulinum spores, low concentrations of competing microbes, high temperatures, protein source, and anoxia) spores commence vegetative growth and begin to produce BoNT (Espelund and Klaveness, 2014; Rocke and Bollinger, 2007). Decomposition of dead organisms that carry $C$. botulinum spores may provide the conditions required for optimal vegetative cell growth and BoNT production (Espelund and Klaveness, 2014). Mass deposition and decomposition of Cladophora glomerata, a common green alga in the Great Lakes, has been proposed as a driver of $C$. botulinum neurotoxin type $\mathrm{E}$ (BoNT/E) production (Byappanahalli and Whitman, 2009; Chun et al., 2013; Wijesinghe et al., 2015). BoNT/E or $C$. 
botulinum spores have also been detected in fish (Getchell et al., 2006) and invertebrates (PerezFuentetaja et al., 2011) in the Great Lakes. For avian botulism to affect non-scavenging bird species, BoNT/E must either be transferred through food webs from substrates containing BoNT/E to live prey, and from live prey to birds, or inadvertently consumed by birds in pursuit of live prey (Espelund and Klaveness, 2014; Getchell et al., 2006). Additionally, transmission of BoNT/E through food webs must occur in locations that are used by foraging waterbirds, many of which are migratory and only temporarily reside in the Great Lakes. Avian botulism type E outbreaks are therefore driven by factors including spatiotemporal distribution patterns of $C$. botulinum toxin, prey items, and birds, as well as vulnerability to intoxication of prey and birds.

The earliest recorded avian botulism die-offs in Lake Michigan occurred throughout the 1960s (Fay et al., 1965), in 1976, and in the early 1980s (Brand et al., 1988). Outbreaks were not recorded again until the late 1990s. However, since the late 1990s, there have been regular dieoffs in the Great Lakes. Recent avian botulism outbreaks in Lake Michigan began in 2006, about the same time that invasive round gobies (Neogobius melanostomus) appeared in annual surveys of prey fish abundance in Lake Michigan (Madenjian et al., 2014) and coincident with the recent expansion and population growth of invasive dreissenid mussels (Nalepa et al., 2010; Nalepa et al., 2014). Dreissenid mussels, including both zebra (Dreissena polymorpha) and quagga (D. bugensis) mussels, have dramatically altered the Lake Michigan food web through filtration of phytoplankton and sequestering of carbon into the nearshore benthos (Heath et al., 1995; Hecky et al., 2004; Nalepa et al., 2009). Related effects include an increase in water clarity and transition of nearshore benthic substrate into extensive mussel beds which enhanced the growth of benthic algae (Auer et al., 2010). Recent studies also highlight the potential for dreissenid 
mussels to influence the flow of energy and nutrients (Mosley and Bootsma, 2015; Tyner et al., 2015) in Lake Michigan.

Unlike most Lake Michigan prey fish, round gobies, particularly larger individuals, consume dreissenid mussels (Barton et al., 2005; Bunnell et al., 2005; Campbell et al., 2009; Burkett and Jude, 2015). Thus, round gobies provide a potential link between mussel-bound nutrients (and toxins) and higher trophic levels (Hebert et al., 2014; Poste and Ozersky, 2013), including piscivorous waterbirds in the Great Lakes. Based on gut content examinations of birds from avian botulism type E outbreaks on lakes Erie and Ontario in 2000 - 2002, round gobies were an important prey item in affected birds (Hannett et al., 2011).

Several waterbird species have been affected by BoNT/E in Lake Michigan in recent outbreaks (Chipault et al., 2015). Primary species have included piscivores such as common loon (Gavia immer), double-crested cormorant (Phalacrocorax auritus), and red-breasted merganser (Mergus serrator), as well as molluscivorous ducks (long-tailed duck [Clangula hyemalis] and white-winged scoter [Melanitta fusca]), and generalists such as ring-billed gulls (Larus delawarensis) and grebes (Podiceps spp.), suggesting that there may be several food web linkages relevant to BoNT/E transmission to birds. Additionally, some of these species are migratory and forage in the Great Lakes for short periods of time (e.g., common loon, long-tailed duck), while others are summer residents of Lake Michigan (e.g., ring-billed gull, double-crested cormorant). This is relevant because seasonal patterns in peak reported avian mortality on Lake Michigan have varied among years, suggesting important spatial and temporal differences in transmission patterns. Transmission of the toxin is perhaps influenced by dynamics of BoNT/E production and distribution coupled with patterns of seasonal waterbird abundance on Lake Michigan (Chipault et al., 2015). 
In their non-native ranges, round gobies have become important prey and have caused shifts in the foraging behavior of some piscivorous bird species (Jakubas, 2004; Johnson et al., 2015; Tucker and Seefelt, 2014). After round gobies were introduced to Lake Ontario, they became the dominant prey of breeding double-crested cormorants at Pigeon and Snake Islands. Moreover, seasonal shifts in cormorant diets that corresponded with prey abundance before the introduction of round gobies were no longer observed (Johnson et al., 2010). Similarly, round gobies became the dominant prey of double-crested cormorants at the Beaver Archipelago in Lake Michigan, and other prey items became less important (Van Guilder and Seefelt, 2013). To our knowledge, the response of other waterbird species to the round goby invasion has not been published.

Round gobies themselves consume a variety of prey species in addition to dreissenid mussels, including chironomids, mayflies, Mysis diluviana, Gammarus spp., and various zooplankton (Brush et al., 2012; Raby et al., 2010; Walsh et al., 2007). Gut content analyses of round gobies in the Great Lakes have revealed that round gobies of a wide range of size classes ate dreissenid mussels, but the contribution of dreissenid mussels to the diets of round gobies generally increased with fish size (Burkett and Jude, 2015; Campbell et al., 2009; Ray and Corkum, 1997; Walsh et al., 2007). In studies where dreissenid mussels were absent or locally depleted, other benthic invertebrates dominated round goby diets (Barton et al., 2005; Campbell et al., 2009; Carman et al., 2006; Ray and Corkum, 1997).

Recent avian botulism die-offs offered an opportunity to examine the gut contents of waterbirds feeding in Lake Michigan in order to generate hypotheses about the location of BoNT/E in the environment and the potential pathways for the transfer of the toxin in food webs. Because BoNT/E affects birds acutely (Smith and Sugiyama, 1988), knowledge of BoNT/E 
positive bird diets just prior to succumbing to the toxin could provide clues about which prey items are important in the transfer of the toxin. Previous studies have identified round gobies as an important prey item for predatory waterbirds in the Great Lakes (Johnson et al., 2015), but their importance in the diets of birds that succumb to BoNT/E is not known. We examined the importance of round gobies and other prey items consumed by waterbirds collected in Lake Michigan during years with BoNT/E outbreaks by plotting percent abundance of each prey item against its frequency of occurrence. We explored differences in diet composition among bird species, by BoNT/E assay results, and by collection type (i.e., moribund birds and carcasses vs. culled birds). We also examined size-class distribution of fish prey in order to make inferences about trophic pathways of the toxin in the lower food web, with special emphasis on understanding the role of round goby and dreissenid mussels in toxin transfer.

\section{Methods}

\section{BoNT/E-assayed bird samples}

Between June and November, 2010 - 2012, sick or dead birds were collected from fixed beach transects located in three areas around northern Lake Michigan (Door County, Wisconsin and neighboring counties, eastern Upper Peninsula of Michigan, and Sleeping Bear Dunes National Lakeshore, Michigan) (Figure 1). Carcasses were collected by the National Park Service and National Park Service Volunteers-in-Parks, Common Coast Research and Conservation, and the United States Geological Survey (USGS) personnel, partners, and volunteers (Chipault et al., 2015). Due to increased local awareness of avian botulism-related mortality, some bird carcasses were also reported and collected from nearby areas off-transect. To ensure that the presence of BoNT/E was indicative of toxin ingested by a live bird and not 
toxin produced within the carcass post-mortem, only intact carcasses that showed no signs of decomposition (i.e., no foul odor, no maggots, feathers did not pull out easily, eyes present) were collected (Chipault et al., 2015). Bird carcasses in suitable condition were sent to the USGS National Wildlife Health Center (NWHC) in Madison, Wisconsin to be tested for BoNT/E using mouse bioassays (AOAC, 2001; Chipault et al., 2015). Birds that tested positive or negative for BoNT/E are hereafter referred to as BoNT/E-positive or BoNT/E-negative, respectively. At NWHC, gastrointestinal (GI) tracts were removed from all carcasses that were tested for BoNT/E. Botulinum toxin was inactivated with a $10 \%$ formaldehyde bath, and GI tracts were preserved in $95 \%$ ethanol.

\section{BoNT/E-free cormorants}

In order to address potential diet-related biases associated with sampling moribund/dead birds, and to compare diets of birds affected by botulism with healthy birds, we investigated gut contents of apparently healthy cormorants that were culled from northern Lake Michigan as part of cormorant control efforts by the United States Department of Agriculture and the Band of Ottawa and Chippewa Indians Department of Natural Resources. These cormorants were obtained following United States Fish and Wildlife Service regulations (CFR 21.47). Culled cormorants were not tested for BoNT/E, but were considered BoNT/E-free because they were not visibly injured or sick before they were shot, and there were no reports of botulism related deaths of double-crested cormorants in the area (Figure 1) during the period of collection. At Bellow Island (BELL), Grand Traverse Bay, Michigan, cormorants were culled from 10:00 to13:00, 12 June 2012. At Gull Island and Little Gull Island (GULL), Michigan and the Ludington Pump Storage Breakwall (LPSB), Michigan, cormorants were culled from 17:00 to 21:00, 28 June 2012 and 24 July 2012, respectively. Culled birds were immediately placed on ice 
and then frozen $\left(-20^{\circ} \mathrm{C}\right)$ for later processing. Placing the birds on ice likely slowed post-mortem digestion and freezing birds halted it. The amount of time the cormorants were on ice before they were transferred to the freezer was approximately 5.5, 2.0, and 6.5 hours for BELL, GULL, and LPSB birds, respectively. The birds were later thawed and the GI tracts removed and preserved in $95 \%$ ethanol.

\section{Gut content analysis for all birds}

Sex and age class (adult, juvenile) were recorded for all birds where possible. Contents of the esophagus, proventriculus, and gizzard were removed separately, and prey items were washed through nested sieves $(2.0 \mathrm{~mm}, 1.0 \mathrm{~mm}$, and $0.6 \mathrm{~mm})$. To reduce bias against soft-bodied prey, many diet studies examine only the esophageal contents of birds (Anderson et al., 2008); however, in this study, birds collected during die-offs were moribund, or $1-2$ days postmortem, and often had no prey items left in their esophagus. Because sample sizes were already limited, we pooled esophagus, proventriculus, and gizzard contents for each bird examined. The GI tracts of some birds were empty and could not be included in the diet analysis.

Prey items were sorted into the following categories: diagnostic fish bones (cleithra, otolith, dentary, premaxillary, dentigirous plate, pharyngeal branchial plate, and operculum), miscellaneous bones (vertebrae, ribs, fin rays, etc.), intact fish, insects, mussels, crayfish, parasites, and other (stones, sand, feathers, etc.). Items in each category were identified and enumerated. The minimum number of fish consumed by each bird was determined by summing the number of each diagnostic bone found in a bird and dividing by the number of bones that belong anatomically in one fish. The same principle was applied to enumerate the minimum number of macroinvertebrate species consumed. For instance, because each dreissenid mussel 
has two umbos, the number of umbos in each gut was counted and divided by two to calculate the minimum number of dreissenids present.

Dentary bones were used to estimate the total length (TL) of round gobies because intact dentary bones occurred more frequently than other types of diagnostic bones found in GI tracts (Essian, 2015), and because there is a strong relationship between dentary length and TL of round gobies (Dietrich et al., 2006). Cleithra and otoliths were used to estimate the lengths of alewives (Alosa pseudoharengus) and yellow perch (Perca flavescens) based on published regression coefficients (Burnett et al., 2002; Scharf et al., 1998). When possible, grand mean TL of fish consumed was calculated by averaging TL of each individual fish of the same species consumed by individual birds, and then averaging those values. All error measurements are standard error of grand mean TL.

Diets of birds sampled in this study were characterized by calculating 1) the frequency of occurrence (\% FO) of each prey item, and 2) the relative contribution of each prey item to the sample, by percent abundance (proportion of the total number of prey found in gut contents). Data were best represented by percentages and were subject to unit sum constraint, non-normal distribution, and variance inequality. To compare percent abundance of prey items in the diets of culled cormorants across locations, we compared mean percent abundances of prey items among locations using Kruskal-Wallis analyses. Within locations, we compared the diets of cormorants by sex and age class using Mann-Whitney $U$ tests. Use of percent abundance instead of percent biomass will result in an overestimation of the caloric importance of invertebrates in the diets of birds. However, we decided to give equal weight to all sizes of prey in this analysis, because smaller prey items could be important in the transfer of BoNT/E; and comparisons of fish biomass among bird groups was not presented herein because, based on visual observation, we 
concluded it did not reveal different trends in this dataset than the previously described comparisons of percent abundance.

For each bird species examined, we used modified Costello graphs (Costello, 1990; Marshall and Elliott, 1997) to represent the importance of prey items in terms of mean percent abundance and frequency of occurrence in bird diets. Costello graphs provide a graphical analysis of the importance of prey items in diet samples. Frequency of occurrence is used as the $\mathrm{x}$-axis and percent abundance is used as the $\mathrm{y}$-axis so that prey dominance increases along a diagonal axis moving from the 0 intersect to the upper right hand corner of the graph. BoNT/Epositive and -negative, adult and juvenile, and male and female comparisons were not possible for most species because of limited sample size. Comparisons across BoNT/E-assayed birds collected at different locations around northern Lake Michigan were also not possible because of small sample sizes, and because it was difficult to determine the locations where birds deposited on a beach were foraging when they ingested the toxin and became sick. Sample sizes of common loons were large enough that it was possible to test for differences between the prey contents found in BoNT/E-positive and BoNT/E-negative loons with a Mann-Whitney U test. Round goby size class distributions in the guts of BoNT/E-positive and -negative common loons (size class distributions defined as $30-60 \mathrm{~mm}, 60-90 \mathrm{~mm}, 90-120 \mathrm{~mm}, 120-150 \mathrm{~mm}$, and > $150 \mathrm{~mm}$ ) were compared using G-tests. Additionally, the Mann-Whitney U test was used to compare mean lengths of round gobies consumed by BoNT/E-positive and BoNT/E-negative loons. It was also possible to compare the size-class distributions and mean lengths of round gobies found in culled cormorants across locations using G-tests and a Kruskal-Wallace test, respectively. Following Kruskal-Wallace tests, Dunn's post hoc test was used to determine which sites differed from each other. Non-parametric tests were performed because data were 
checked for normality and did not conform, even after multiple transformations were attempted. Because dreissenid mussels could be ingested by birds indirectly through round gobies, we tested for a correlation between the number of dreissenid mussels and the number of round gobies found in culled double-crested cormorants using a Pearson's correlation test. All statistics were performed using the R 3.2.2 statistical software package. Comparisons were considered statistically significant if $\alpha<0.05$.

For conceptual purposes, we grouped the bird species examined in this study into four general feeding groups when reporting results. We refer to white-winged scoters and long-tailed ducks as molluscivorous ducks, although they are not limited to bivalve prey (Anderson and Lovvorn, 2012; Anderson et al., 2008; Ross et al., 2005). Grebes are aquatic generalists (Piersma, 1988) and ring-billed gulls are aquatic-terrestrial generalists (Pollet et al., 2012). We refer to loons and cormorants as top-level piscivores (Barr, 1996; Doucette et al., 2011), although they will also consume benthic crustaceans.

\section{Results}

Eighty-nine birds (seven species) observed sick or dead and collected from northern Lake Michigan beaches were tested for BoNT/E and gut contents were examined. The GI tracts of 75 of these birds contained prey remains and were included in dietary analysis. The BoNT/E testing yielded positive intoxication results for 57 birds and negative results for 30 birds. The mouse assay result was equivocal for one red-necked grebe (Podiceps grisegena) and one common loon; the equivocal loon was excluded from statistical comparisons of BoNT/E-positive and BoNT/E-negative loons. The equivocal red-necked grebe was included in the Costello graphs because the sample size was small $(n=5)$, therefore the gut contents of each red-necked grebe 
sampled contributed substantially to our interpretation of general dietary trends of red-necked grebes on Lake Michigan. One BoNT/E-negative loon exhibited signs of lead poisoning (there was a lead fishing sinker in the gizzard and the lining of the GI tract was black), so it was excluded from all analyses. Seventy-seven double-crested cormorants that were assumed to be BoNT/E-free were culled at three breeding colonies on northern Lake Michigan. Sixty-three of these birds had prey remains in their GI tracts and were included in the diet analysis. Seventy percent were male and $72 \%$ were adults (Table 1 ).

\section{Molluscivorous ducks}

All long-tailed ducks $(n=2)$ and white-winged scoters $(n=6)$ examined in this study were BoNT/E-positive. Prey items that occurred most frequently in the diets of long-tailed ducks and white-winged scoters were dreissenid mussels (100\% FO in both species) and round gobies (50\% FO in long-tailed ducks and 83\% FO in white-winged scoters) (Figure 2a-b). Dreissenid mussels composed the highest mean percent abundance of the prey items in long-tailed ducks and white-winged scoters (Figure 2a-b). Their gut contents were usually degraded and most of the hard parts (mussel shells and fish bones) were fragmented. One intact round goby dentary bone was found in a long-tailed duck and four were found in white-winged scoters. The grand mean lengths of round gobies consumed by long-tailed ducks and white-winged scoters were 56 $\mathrm{mm}$ and $73 \pm 3 \mathrm{~mm}$, respectively; but, because few bones were intact, averages for both species were based on low sample sizes. As expected, dreissenid mussels were more important in the diets of molluscivorous ducks than other bird species (Figure 2). Unlike previous studies on the Great Lakes (Peterson and Ellarson, 1977, Ross et al., 2005), amphipods were not present in the gut contents of long-tailed ducks.

\section{Aquatic generalists}


Nine of 10 grebes examined in this study tested positive for BoNT/E while one rednecked grebe had equivocal test results. Prey species that occurred most frequently in horned grebes (Podiceps auritus) included round gobies and terrestrial insects (both 100\% FO), with round gobies composing the largest mean percent abundance of prey items (Figure 2c). Prey items that occurred most frequently and composed the highest mean percent abundance in rednecked grebes were terrestrial insects (Figure 2d). Individual, fragmented dreissenid mussel shells were found in one horned and one red-necked grebe. Both birds also consumed round gobies, so it is possible that dreissenids were indirectly consumed by the birds. One horned grebe consumed an alewife (Alosa pseudoharengus), and its estimated length was $46 \mathrm{~mm}$. The estimated lengths of round gobies ranged from 47 to $109 \mathrm{~mm}$ (grand mean TL $=71 \pm 3 \mathrm{~mm}$ ) in horned grebes and from 47 to $122 \mathrm{~mm}(\mathrm{TL}=73 \mathrm{~mm})$ in the single red-necked grebe that contained intact round goby bones (Figure 3a-b). Grebes, the aquatic generalists in this study, tended to consume smaller gobies than other feeding groups. This could have implications for the transmission of BoNT/E if, as some studies suggest, the feeding habits of round gobies differ among size classes (Raby et al., 2010; Brush et al., 2012). Despite being categorized as "aquatic generalists" a priori, all grebes that were examined consumed terrestrial insects (Hemiptera, Hymenoptera, and Coleoptera). Terrestrial insects were important in the diets of grebes compared with other bird feeding groups (Figure 2).

\section{Aquatic-terrestrial generalists}

There were 19 ring-billed gulls from which GI tracts were collected during this study period; 15 of 19 ring-billed gulls tested positive for BoNT/E. As found in grebes, prey items that occurred most frequently in ring-billed gulls were round gobies $(74 \% \mathrm{FO})$ and terrestrial insects 
(68\% FO) (Figure 2e). On average, terrestrial insects were the most abundant prey item in the gut contents of ring-billed gulls (Figure 2e). A small sample size for BoNT/E-negative gulls precluded meaningful statistical comparisons of the diets of BoNT/E-positive and BoNT/Enegative ring-billed gulls, but visual comparison suggests that terrestrial insects and round gobies remained the two most important prey items for both groups of gulls (Figure 2e). Chironomids were also found in four ring-billed gulls and had the highest raw count of any prey item found in ring-billed gulls. However, 119 of 144 chironomid larvae in ring-billed gull guts were found in one bird. Similarly, 108 of 151 terrestrial insects observed in ring-billed gulls were found in one bird, suggesting opportunistic feeding on patches of prey.

Ring-billed gulls that consumed round gobies tended to consume a small number of round gobies in larger size classes (121 $\pm 12 \mathrm{~mm} \mathrm{TL})$, although one individual did consume a large number of round gobies $<90 \mathrm{~mm}$ TL (Figure 3c). Ring-billed gulls also consumed alewives from a wide range of size classes $(49-121 \mathrm{~mm}$, grand mean $\mathrm{TL}=72 \pm 6 \mathrm{~mm})$.

\section{Top-level piscivores}

Of the 38 common loons examined, 31 contained prey items in their GI tracts (13 BoNT/E-negative loons, 17 BoNT/E-positive loons, and one loon with an equivocal test result which was not included in analyses). Seven of eight common loons with empty GI tracts tested negative for BoNT/E. The most frequently occurring prey items in common loons were round gobies (100\% FO). Dreissenid mussels and crayfish occurred less frequently in gut contents (Figure 2f). Round gobies composed the highest mean percent abundance of loon gut contents (Figure 2f), and were the sole prey item in $52 \%$ of loons. The size class distributions of consumed round gobies did not differ between BoNT/E-positive and -negative common loons (Figure 3d; G $[\mathrm{df}=4]=3.79, p=0.43$ ), nor did mean estimated lengths of round gobies differ 
(Mann-Whitney, $\mathrm{U}=7113, p=0.91$ ). The estimated TL of round gobies ranged from 47 to 207 $\mathrm{mm}$ (grand mean $\mathrm{TL}=110 \pm 6 \mathrm{~mm}$ ) in common loons examined (Figure $3 \mathrm{~d}$ ). Percent abundances of crayfish were lower in BoNT/E-positive birds (Mann-Whitney, $\mathrm{U}=73.5, p=$ 0.03); overall, crayfish were relatively unimportant for the sampled loons (Figure 2f). No other significant differences were detected between diets of BoNT/E-positive and -negative common loons.

Of the seven BoNT/E-assayed double-crested cormorants (all BoNT/E-positive) that had prey items in their gut contents, the most frequently occurring prey items found were round gobies (100\% FO) and dreissenid mussels (71\% FO) (Figure 2g). Round gobies composed the largest mean percent abundance of prey consumed by cormorants (Figure 2g). Double-crested cormorants consumed round gobies that ranged from 54 to $189 \mathrm{~mm}$ (grand mean TL $=114 \pm 6$ $\mathrm{mm}$ ) (Figure 3e), and generally consumed round gobies in larger size classes. Despite differences in collection methods used, and the observation in this study that the number of intact prey items was generally greater in shot cormorants than in birds found sick or dead, prey composition of BoNT/E-positive and BoNT/E-free double-crested cormorants appeared to be similar (Figure 2gh). Many cormorants at BELL had empty guts (45\%), whereas proportionately fewer birds at GULL (21\%) and LPSB (4\%) had empty guts. These differences were likely due to the time of day that cormorants were culled. Although there were differences in percent abundance of round gobies, alewives, and dreissenids consumed by BoNT/E-free cormorants among locations (Table 2), round gobies were found more frequently than all other prey items at all locations (Figure 2h). Comparisons across locations showed that round gobies also composed the highest mean percent abundance of gut contents at BELL and LPSB, and the second-highest mean percent abundance of gut contents at GULL (Table 2). The prey species with the highest mean percent 
abundance at GULL was the alewife. At every location, round gobies composed a higher percent abundance of the gut contents of juvenile cormorants than adult cormorants; conversely, alewives composed a higher percent abundance of the gut contents of adult cormorants than juvenile cormorants (Figure 4a). Juvenile culled cormorants consumed round gobies at a significantly higher mean percent abundance than adults at LPSB, and the difference in percent abundance of alewives consumed by adult and juvenile cormorants at GULL approached significance (Table 3; Mann-Whitney, $\mathrm{U}=22, p=0.02$ and Mann-Whitney, $\mathrm{U}=81, p=0.06$, respectively). Mean percent abundance of dreissenid mussels was lower in female cormorants than males at GULL (Table 3; Mann-Whitney, $\mathrm{U}=37, p=0.02$ ), but dreissenids were more prevalent in females than males at BELL (although sample size was small). There was no difference at LPSB (Figure 4b).

The size range of round gobies consumed by BoNT/E-free double-crested cormorants was $33-226 \mathrm{~mm}$ TL (Table 4). Mean length of round gobies consumed by culled cormorants differed among sites (Kruskal-Wallis, $\mathrm{H}=197.67, p<0.01$ ). The size class distribution of round gobies consumed also differed among locations (Figure 3f-h, G [df $=8]=214.27, p<0.01$ ). Round gobies that were $>90 \mathrm{~mm}$ composed a larger mean percent abundance of the diets of LPSB cormorants than of GULL and BELL cormorants. The size range of alewives consumed by BoNT/E-free double-crested cormorants was $20-162 \mathrm{~mm}$ (Table 4). Yellow perch (Perca flavescens) composed $<3 \%$ of the gut contents at all locations and were $44-146 \mathrm{~mm}$ TL (Table 4). Yellow perch were not found in the gut contents of BELL double-crested cormorants. Dreissenid mussels composed a higher mean percent abundance of the gut contents at LPSB than at GULL and BELL (Table 2, Figure 2h). Abundances of dreissenid mussels and round gobies in culled cormorants were positively correlated when sites were pooled together (Pearson 
correlation, $\left.\mathrm{r}^{2}=0.70, p<0.01\right)$. Dreissenid mussels composed a higher mean percent abundance of gizzard contents $(24 \pm 6 \%)$ than esophageal contents $(9 \pm 5 \%)$ in culled cormorants, suggesting that retention time for dreissenid shells in cormorant gizzards is high compared with other prey items. Therefore, dreissenid mussels may be overrepresented in the diets of doublecrested cormorants, including those that were collected sick or dead on beaches.

\section{Discussion}

The gut contents characterized in this study included a broad variety of prey and generally aligned with known foraging strategies of the bird species involved. For example, molluscivorous ducks consumed substantial proportions of dreissenid mussels; and piscivorous bird species ate primarily fish. In order to elucidate potential BoNT/E food web pathways, we looked for commonalities in diet across botulism-affected species. Round gobies were the most important prey consumed in four of seven affected species that were examined (common loon, double-crested cormorant, ring-billed gull, and horned grebe). These results suggest that round gobies may be a live-fish pathway for the transfer of botulinum toxin to fish-eating bird species studied here. Alewives were implicated in avian botulism die-offs in the 1960s (Lafrancois et al., 2011); in this study, alewives were important prey for both species that are breeding residents in Lake Michigan (double-crested cormorants and ring-billed gulls). However, alewives were nearly absent from diets of fall migrants in this study (common loons, horned grebes, red-necked grebes, white-winged scoters, and long-tailed ducks). Dreissenid mussels were the most important prey item found in molluscivorous ducks (white-winged scoter and long-tailed duck), but they were relatively unimportant in other species (except double-crested cormorants). Furthermore, several species showed wide diet breadth, including ring-billed gull and red-necked grebe. A finding of note for grebes, considered aquatic generalists, was the substantial inclusion 
of terrestrial insects in their diet. Given the variety in diet across BoNT/E-positive bird species found during shoreline surveillance of northern Lake Michigan in 2010 - 2012, and the fact that BoNT/E-negative and BoNT/E-free birds had similar diets as BoNT/E-positive birds, no single prey item or suite of prey items were indicated, but our findings suggest multiple potential toxin pathways.

In addition to insects that are available on land to shorebirds such as gulls, large numbers of insects may be available on the surface of the water when they are blown offshore during wind events (Denemark et al, 2010; Isard et al., 2001), and form mats of floating insects (Needham, 1900). Terrestrial insects have been found to be important prey for Great Lakes piscivores (Roseman et al., 2014), and could be easily exploited by grebes, which are already prone to consuming insects (Chamberlin, 1977; Wetmore, 1924). The waterbird carcasses themselves may be an attractive habitat for aquatic and terrestrial macroinvertebrates. Large concentrations of amphipods have been observed on floating waterbird carcasses in shallow nearshore water in Lake Michigan during the timeframe of this study, and large concentrations of coccinellid species have been observed on beached carcasses (T. Tucker, CCS-Dynamac, USGS, personal communication). For bird species that included insects and soft-bodied invertebrates in their diet, an analogous pathway to the carcass-maggot BoNT pathway involving toxin transfer through insect activity on decaying carcasses is possible, especially for scavenging species such as ring-billed gulls. Alternatively, beached Cladophora mats may accumulate terrestrial insects and provide feeding opportunities for both round gobies and waterbirds once mats are drawn back into the lake, which might also be the mechanism by which grebes ingested substantial quantities of terrestrial insects (United States Department of the Interior, 1968). 
Round gobies were the dominant prey fish for Lake Michigan piscivorous waterbirds examined in this study. Round gobies were also represented in a broad range of bird species that are not usually identified as primarily piscivorous; the frequency of occurrence of round gobies within bird diets ranged from $40 \%$ in red-necked grebes to $100 \%$ in common loons (mean $78 \pm$ 9\%). Moreover, two of three bird species that were recorded in highest numbers during the 3 years of beach surveillance concurrent with botulism mortality events (common loon and horned grebe; Chipault et al., 2015) had gut contents dominated by round gobies. Based on this evidence, it is likely that a live-fish transfer pathway for moving BoNT/E to upper levels of the food web occurs in Lake Michigan. Further, dreissenid mussel shells were observed in the guts of piscivorous species, implying that the toxin transfer pathway may involve mussels either directly, through consumption of mussels by birds that are foraging in benthic environments, or indirectly, through bird consumption of live fish that had previously consumed mussels.

For molluscivorous species, such as long-tailed duck and white-winged scoter, direct mussel consumption offers a plausible pathway for BONT/E transfer. Long-tailed ducks were the most recorded species during shoreline surveillance of northern Lake Michigan in 2010 and the second-highest recorded species for the 3-year surveillance period that corresponded with our gut content study (Chipault et al., 2015). Furthermore, all molluscivores in this study tested positive for BoNT/E and all consumed mussels. Given their diet profiles, it is more likely that these birds succumbed to direct transfer of toxin from the mussels, although they did consume fish, which may implicate an alternate BoNT/E transfer method. It is important to reiterate that this inference is based on the gut contents of a small number of individuals from each species. We recognize that the nature of our sampling methods is likely to have underrepresented smaller, soft-bodied prey types, particularly in those bird species adapted for consumption of molluscs, which use 
highly reinforced gizzards, and so we may be underestimating the chances of soft-bodied prey (such as insects and amphipods) contributing to BoNT/E transfer. Despite small sample sizes and the limitations of our sampling methods, the substantial dependence on mussels is suggestive and warrants further exploration of this potential pathway.

Many studies have described biases associated with gut content analyses in waterbirds, including studies on some species examined in this study (Anderson et al., 2008; Brown and Ewins, 1996; Seefelt and Gillingham, 2006). Because many birds in this study were collected moribund or post-mortem, their gut contents were highly degraded (there was little or no tissue attached to the bones of vertebrates, and soft-bodied prey would have been completely digested), and most prey identification was based on bones from fish and invertebrate exoskeletons. As a result, data from the gut contents undoubtedly over-represent vertebrates and hard-bodied species (such as dreissenid mussels) that were consumed by prey fish or birds and under-represent all soft-bodied prey (such as amphipods). Amphipods are a key prey item of nesting white-winged scoters in shallow prairie lakes (Brown and Fredrickson, 1986), and previous studies have suggested that they may be important prey for long-tailed ducks wintering on the Great Lakes (Peterson and Ellarson, 1977; Ross et al., 2005). In contrast to previous studies, amphipods were absent from the gut contents of molluscivorous ducks in this study. An early study found that Diporeia spp. composed $82 \%$ of the amphipods found in long-tailed duck gut contents (Peterson and Ellarson, 1977). Absence of amphipods in the current study may reflect a rapid decline of Diporeia spp. at shallow depths in Lake Michigan since the introduction of dreissenid mussels (Nalepa, 2009), rather than a bias against soft-bodied prey in gut contents. Somewhat high densities (190 amphipods $/ \mathrm{m}^{2}$ ) of other amphipod species, including Gammarus spp. and Hyalella spp., have been detected at shallow depths in recent years (Harvey Bootsma, University of 
Wisconsin-Milwaukee, School of Freshwater Sciences, 2016, personal communication). It is not clear whether or not these species are being consumed by waterbirds on Lake Michigan, but a bias against soft-bodied prey in this study would likely be most important for long-tailed duck and white-winged scoter diets and less important for known piscivores such as loons and doublecrested cormorants (Barr, 1996; Seefelt and Gillingham, 2006). A more detailed diet analyses from all of these species would be useful in understanding possible BoNT/E transfer pathways.

It is clear that there are food web shifts occurring in the Great Lakes ecosystem that might be affecting avian botulism type E dynamics. The fact that diets of the most BoNT/Eaffected birds were dominated by invasive fish or mussels suggests that trophic pathways that did not exist in Lake Michigan decades ago are now potentially critical for BoNT/E transfer. However, since some BoNT/E-negative waterbirds and BoNT/E-free cormorants also consumed dreissenid mussels or round gobies, suggesting that not all invasive food items contain debilitating quantities of BoNT/E, although it is important to note that the cause of death is not known for BoNT/E-negative birds.

Given that the piscivorous species examined seem to have shifted to the round goby as abundant forage and molluscivorous birds now have ample dreissenid prey, it will be important in the future to determine when consumption leads to lethality, and when it does not. It is possible that BoNT/E was consumed with round goby or dreissenid prey, but toxin levels were too low to detect via assay in BoNT/E-negative birds (Chipault et al., 2015); however, culled double-crested cormorants also consumed large numbers of round gobies and mussels and were apparently unaffected. No information is available yet to clarify the dose and ingestion timeline needed to induce death in the bird species examined in this study and so we are unable to discern 
whether unaffected birds could be ingesting sublethal levels of BoNT/E with the diets in our study.

As with the sensitivity of bird species to BoNT/E, the prevalence and quantity of toxin in different species or size classes of prey are poorly understood. Die-offs of several fish species, including round gobies, have been attributed to BoNT/E (Getchell et al., 2006). BoNT/E intoxicated fish may also exhibit symptoms that increase their susceptibility to predation by fisheating birds, such as hyper-pigmentation and erratic swimming behavior (Yule et al., 2006a, 2006b). Ontogenetic shifts in round goby diets could also result in varying prevalence of BoNT/E intoxication by goby size class, particularly if the transfer of BoNT/E to round goby is linked to dreissenid consumption. Diet studies of round gobies in the Great Lakes show that feeding strategies differ based on gape size, depth, and substrate (Ray and Corkum, 1997; Walsh et al., 2007). In general, prevalence of dreissenid mussels in round goby diets increases with size where dreissenids are available (Ray and Corkum, 1997; Barton et al., 2005; Walsh et al., 2007). If the likelihood of BoNT/E transmission differs between dreissenid mussel-based pathways and alternate pathways, round goby size selection by birds could influence the likelihood of BoNT/E impact.

Ring-billed gulls tended to consume relatively large round gobies in small quantities, although one BoNT/E-negative ring-billed gull consumed a large number of relatively small round gobies. Differences in the number and sizes of round gobies consumed by ring-billed gulls were likely related to foraging strategies of ring-billed gulls, and to availability and distribution of round gobies in habitats where ring-billed gulls are able to capture prey. Because they are surface gleaners and scavengers, ring-billed gulls must either consume live round gobies from shallow water, or from the surface. Round gobies that are BoNT/E-intoxicated may swim 
erratically toward the surface (Yule et al., 2006a; Yule et al., 2006b), so it is possible for ringbilled gulls to capture intoxicated round gobies at the surface. Alternatively, ring-billed gulls could consume dead round gobies that have washed ashore; this possibility is supported by the fact that die-offs of round gobies have occurred in the same years as avian botulism die-offs on Lake Michigan. During 2011, a comparatively low avian botulism mortality year overall, ringbilled gulls were impacted more than any other species detected during shoreline surveillance (Chipault et al., 2015). Ring-billed gulls can provide unique insight into avian botulism type $\mathrm{E}$ dynamics because they tend to be the species most affected in summer.

Piscivores consumed round gobies of all size classes. Diets of double-crested cormorants skewed toward larger round gobies compared with common loons, which consumed round gobies evenly across size classes. These differences could reflect spatial and temporal differences in round goby distribution throughout the lake. Double-crested cormorants feed in shallower, nearshore habitats during the round goby spawning season (Kornis et al., 2012), enhancing predation likelihood on larger round gobies during a period when they are concentrated. Common loons present on Lake Michigan during fall migration tend to forage farther offshore, and in deeper water than other waterbird species (Kenow et al., in press). Around the same time of year, round gobies are moving from nearshore sites into deeper water. The distribution, size class structure, and diets of round gobies in deeper offshore sites are not well known, but dreissenid mussels may not be as important as other macroinvertebrate prey in offshore habitats (Walsh et al., 2007). Combining the behavior of these adult round gobies with the tendency for large round gobies to consume dreissenids may result in a greater likelihood of BoNT/E presence in larger round gobies and greater impact on species that tend to consume them. Horned grebes, all of which tested BoNT/E-positive, consumed smaller round gobies than 
other bird species, likely because they are limited by gape size (Piersma, 1988). However, even the smallest round gobies found in horned grebes were large enough to consume smaller mussels, suggesting that round goby size is not the only determinant of BoNT/E transfer. BoNT/E assays on round gobies of varying size classes are needed to more fully explore this relationship between round goby ecology, size selection by birds, and likelihood of BoNT/E transfer.

Despite dominance of round gobies in gut contents of many birds in this study and, more generally, in piscivore diets in the Great Lakes since the early 2000s (Johnson et al., 2015; Van Guilder and Seefelt, 2013), differences in percent abundance of prey items found in gut contents of BoNT/E-free double-crested cormorants collected at three locations on separate dates suggest that diets of fish-eating birds in Lake Michigan vary spatially and temporally within one year. Based on percent abundance, alewives were more important in the gut contents of cormorants from GULL than they were in the gut contents of cormorants from other locations. Alewives were found less frequently than round gobies in GULL cormorants, but they composed nearly the same mean percent abundance. Individual cormorants often contained large numbers of a single prey species, particularly alewives, which suggests that double-crested cormorants will focus their foraging efforts on patches of abundant prey. Further spatial and temporal resolution of sites where birds might become intoxicated will be helpful in understanding the role of prey species, including round goby, to avian botulism type E mortality.

Although the dominant role of round gobies in the diets of fish-eating waterbirds may not vary annually, the impact of BoNT/E on individual bird species does vary (Chipault et al., 2015), probably in relation to other important ecological factors. For large-scale die-offs to occur, the conditions that promote BoNT/E production and transfer through food webs must coincide with 
the presence of large numbers of waterbirds in the Lake Michigan ecosystem (e.g., during autumn migration). The C. botulinum spore is not harmful until it is exposed to environmental conditions that promote vegetative growth and BoNT/E production. Low water levels, high surface temperatures, and mass blooms of Cladophora may extend the period and area suitable for BoNT/E production, increasing the likelihood that birds will encounter the toxin (Lafrancois et al., 2011).

Prey availability and activity in the habitats where BoNT/E is produced could also affect the likelihood that a bird will encounter the toxin. For example, larger round gobies may displace smaller round gobies from rocky habitats to sandy habitats (Ray and Corkum, 2001). Predators that focus their foraging efforts on smaller round gobies that have been displaced to peripheral habitats may be exposed to different trophic pathways than avian predators that focus their foraging efforts on rocky areas, potentially affecting the likelihood that a predator will encounter the toxin. To predict the impact of botulism outbreaks on Great Lakes waterbirds, it will be critical to understand the interplay between spatial and temporal trends of $C$. botulinum toxin production in the Great Lakes as it relates to foraging strategies and habitat use of Great Lakes waterbirds and their prey items.

\section{Conclusion}

While there were spatial and temporal differences in diet composition of waterbirds within and among bird species, our data support several potential BoNT/E pathways important to waterbirds of Lake Michigan including: 1) A direct toxin pathway from dreissenids to molluscivorous birds. 
2) A fish-based toxin pathway for piscivorous birds, potentially involving BoNT/E transfer from benthic prey (including dreissenids) to round gobies and then to piscivorous birds. While other fish were observed in bird gut contents in this study (e.g., alewives), predation on round gobies by waterbirds of Lake Michigan was common across species and across large spatial scales, suggesting that round gobies could be important vectors for transferring BoNT/E to waterbirds. Size classes of round gobies consumed varied among bird species and may be important for understanding the likelihood of intoxication of both the prey fish and their predators.

3) A pathway involving bird consumption of toxin-laden terrestrial invertebrates. Terrestrial insects may become more accessible to waterbirds when they are blown offshore and form concentrated mats. There is also the possibility of transient Cladophora algal mats making terrestrial insects more accessible to birds that feed offshore.

While our data support each of these potential pathways, we note that pathways involving soft-bodied benthic invertebrates such as amphipods, which were underrepresented in our samples, merit further investigation. Future efforts to understand the BoNT/E transfer pathways to waterbirds, and the interannual variability observed in die-offs, should seek to better characterize bird foraging locations, explore the distribution and diet of round gobies, and directly assess BoNT/E presence in round gobies and other key prey items. Moreover, we acknowledge that this study serves as a snapshot of the Lake Michigan food web; factors such as climate change, pollution and nutrient levels, and the introduction of new invasive species could change the ecosystem dynamics important to the understanding of avian botulism type $\mathrm{E}$ in the future. 


\section{Acknowledgments}

We thank the National Park Service (NPS) and U.S. Geological Survey (USGS) for providing support for this project, particularly Sue Jennings and Dan Ray (NPS) and C. LeAnn White, Jonathan Sleeman, Stephen Riley, and Taaja Tucker (USGS). Funding was provided by NPS and USGS via the Great Lakes Restoration Initiative/U.S. Environmental Protection Agency. Northern Michigan University (NMU) also provided equipment and funding through the Excellence in Education Scholarship. We thank personnel from NPS, USGS, Common Coast Research and Conservation, the many dedicated volunteers who collected carcasses from Lake Michigan beaches, and staff at the USGS National Wildlife Health Center for help with carcass necropsies and botulinum toxin testing. We thank all of the NMU volunteers who helped dissect cormorants and sort through gut contents, particularly Rachel Holman, Rachel Koleda, Nicole Griewahn, and Ricki Oldenkamp. We would like to thank Jackie Bird and William Hamilton for helping organize and perform necropsies. We thank Pat Brown and Alec Lindsey for making suggestions that improved this study. We also thank the staff of the Grand Traverse Band of Ottawa and Chippewa Indians Department of Natural Resources and U.S. Department of Agriculture's Animal and Plant Health Inspection Service involved with the cormorant cull following U.S. Fish and Wildlife Service regulations (CFR 21.47). We thank David Jude and an anonymous reviewer for their thoughtful reviews of this manuscript. We also thank Kevin Kenow (USGS) for his helpful review of a draft of this manuscript. Use of trade, product, or firm names is for descriptive purposes only and does not imply endorsement by the U.S. Government.

\section{References}

Anderson, E.M., Lovvorn, J.R., Wilson, M.T., 2008. Reevaluating marine diets of surf and 
white-winged scoters: Interspecific differences and the importance of soft bodied prey. The Condor 110, 285-295.

Anderson, E.M., Lovvorn, J.R., 2012. Gray whales may increase feeding opportunities for avian benthivores. Mar. Ecol. Prog. Ser. 360, 291-296.

Auer, M.T., Tomlinson, L.M., Higgins, S.N., Malkin, S.Y., Howell, E.T., Bootsma, H.A., 2010. Great Lakes Cladophora in the $21^{\text {st }}$ Century: Same algae-different ecosystem. J. Great Lakes Res. 36, 248-255.

Barr, J.F., 1996. Aspects of common loon (Gavia immer) feeding biology on its breeding ground. Hydrobiologia 321, 119-144.

Barton, D.R., Johnson, R.A., Campbell, L., Petruniak, J., Patterson, M., 2005. Effects of round gobies (Neogobius melanostomus) on dreissenid mussels and other invertebrates in eastern Lake Erie, 2002-2004. J. Great Lakes Res. 31, 252-261.

Brand, C.J., Schmitt, S.M., Duncan, R.M., Cooley, T.M., 1988. An outbreak of type E botulism among common loons (Gavia immer) in Michigan’s Upper Peninsula. J. Wildl. Dis. 24, 471-476.

Brown, P.W., Fredrickson, L.H., 1986. Food habits of breeding white-winged scoters Can. J. Zool. 64, 1652-1654.

Brown, K.M., Ewins, P.J., 1996. Technique-dependent biases in determination of diet composition: An example with ring-billed gulls. The Condor. 98, 34-41.

Brush, J.M., Fisk, A.T., Hussey, N.E., Johnson, T.B., 2012. Spatial and seasonal variability in the diet of round goby (Neogobius melanostomus): stable isotopes indicate that stomach contents overestimate the importance of dreissenids. Can. J. Fish. Aquat. Sci. 69, 573586. 
Bunnell, D.B., Johnson, T.B., Knight, C.T., 2005. The impact of introduced round gobies (Neogobius melanostomus) on phosphorous cycling in central Lake Erie. Can. J. Fish. Aquat. Sci. 62, 15-29.

Burkett, E.M., Jude, D.J., 2015. Long-term impacts of invasive round goby Neogobius melanostomus on fish community diversity and diets in the St. Clair River, Michigan. J. Great Lakes Res. 41, 862-872.

Burnett, J.A.D., Ringler, N.H., Lantry, B.F., Johnson, J.H., 2002. Double-crested cormorant predation on yellow perch in the eastern basin of Lake Ontario. J. Great Lakes Res. 28, 202-211.

Byappanahalli, M.N., Whitman, R.L., 2009. Clostridium botulinum type E occurs and grows in the alga Cladophora glomerata. Can. J. Fish. Aquat. Sci. 66, 879-882.

Campbell, L.M., Thacker, R., Barton, D.R., Muir, D.C.G., Greenwood, D., Hecky, R.E., 2009. Re-engineering the eastern Lake Erie littoral food web: The trophic function of non indigenous Ponto-Caspian species. J. Great Lakes Res. 35, 224-321.

Carman, S.M., Janssen, J., Jude, D.J., Berg, M.B., 2006. Diel interactions between prey behaviour and feeding in an invasive fish, the round goby, in a North American river. Freshw. Biol. 51, 742-755.

Chamberlin, M.L., 1977. Observations on the red-necked grebe nesting in Michigan. Wilson Bull. 89, 33-46.

Chipault, J.G., White, C.L., Blehert, D.S., Jennings, S.K., Strom, S.M., 2015. Avian botulism type E in waterbirds of Lake Michigan, 2010-2013. J. Great Lakes Res. 41, 659-664.

Chun, C.L., Ochsner, U., Byappanahalli, M.N., Whitman, R.L., Tepp, W.H., Lin, G., Johnson, E.A., Peller, J., Sadowsky, M.J., 2013. Association of toxin-producing Clostridium 
botulinum with the macroalga Cladophora in the Great Lakes. Environ. Sci. Technol. 47, 2587-2594.

Corkum, L.D., MacInnis, A.J., Wickett, R.G., 1998. Reproductive habits of round gobies. J. Great Lakes Res. Rev. 3, 13-20.

Costello, M.J., 1990. Predator feeding strategy and prey importance: a new graphical analysis. J. Fish Biol. 36, 261-263.

Denemark, E., Losey, J.E., 2010. Causes and consequences of ladybug washups in the Finger Lakes region of New York State (Coleoptera: Coccinellidae). Entomol. Am. 116, 78-88.

Dietrich, J.P., Taraborelli, A.C., Morrison, B.J., Schaner, T., 2006. Allometric relationships between size of calcified structures and round goby total length. N. Am. J. Fish. Manag. 26, 926-931.

Doucette, J., Wissel, B., Somers, C., 2011. Cormorant-fisheries conflicts: Stable isotopes reveal a consistent niche for avian piscivores in diverse food webs. Ecol. Appl. 21, 29873001.

Espelund, M., Klaveness, D., 2014. Botulism outbreaks in natural environments - an update. Front. Microbiol. 5, 1-7.

Essian, D.A., 2015. Stomach content analysis of botulism-affected birds in Lake Michigan (Thesis (M.Sc)), Northern Michigan University, Marquette, MI.

Fay, L.D., Kaufman, O.W., Ryel, L.A., 1965. Mass mortality of water-birds in Lake Michigan 1963-64. Great Lakes Res. Div., University of Michigan (Pub No 13).

Getchell, R.G., Culligan, W.J., Kirchgessner, M., Sutton, C.A., Casey, R.N., Bowser, P.R., 2006. Quantitative polymerase chain reaction assay used to measure the prevalence of Clostridium botulinum type E in fish in the lower Great Lakes. Aquat. Anim. Health 18, $39-50$. 
Hannett, G.E., Stone, W.B., Davis, S.W., Wroblewski, D., 2011. Biodiversity of Clostridium botulinum type $\mathrm{E}$ associated with a large outbreak of botulism in wildlife from Lake Erie and Lake Ontario. Appl. Environ. Microbiol. 77, 1061-1068.

Heath, R.T., Fahnenstiel, G.L., Gardner, W.S., Cavaletto, J.F., Soon-Jin Hwang, S.-J., 1995. Ecosystem-level effects of zebra mussels (Dreissena polymorpha): An enclosure experiment in Saginaw Bay, Lake Huron. J. Great Lakes Res. 21, 501-516.

Hebert, C.E., Chao, J., Johnson, T.B., Rudy, M.D., Sverko, E., Williams, K., Zaruk, D., Arts, M.T., 2014. Ecological tracers track changes in bird diets and possible routes of exposure to type E botulism. J. Great Lakes Res. 40, 64-70.

Hecky, R.E., Smith, R.E.H., Barton, D.R., Guildford, S.J., Taylor, W.D., Charlton, M.N., Howell, T. The nearshore phosphorous shunt: a consequence of ecosystem engineering by dreissenids in the Laurentian Great Lakes. Can. J. Fish. Aquat. Sci. 61, 1285-1293.

Isard, S.A., Kristovich, D.A.R., Gage, S.H., Jones, C.J., 2001. Atmospheric motion systems that influence the redistribution and accumulation of insects on the beaches of the Great Lakes in North America. Aerobiologia 17, 275-291.

Jakubas, D., 2004. The response of grey heron to a rapid increase of the round goby. Waterbirds 27, 304-307.

Johnson, J.H., Ross, R.M., McCullough, R.D., Mathers, A., 2010. Diet shift of double-crested cormorants in eastern Lake Ontario associated with the expansion of the invasive round goby. J. Great Lakes Res. 36, 242-247.

Johnson, J.H., Farquhar, J.H., Klindt, R.M., Mazzocchi, I., Mathers, A., 2015. From yellow perch to round goby: A review of double-crested cormorant diet and fish consumption at three St. Lawrence River colonies, 1999-2013. J. Great Lakes Res. 41, 259-265. 
Kenow, K.P., Ge, Z., Fara, L. J., Houdek, S.C., Lubinski, B.R.., Identifying the origin of waterbird carcasses in Lake Michigan using a neural network source tracking model. J. Great Lakes Res. (2016), http://dx.doi.org/10.1016/j.jg- lr.2016.02.014

Kornis, M.S., Mercado-Silva, N., Vander Zanden, M.J., 2012. Twenty years of invasion: a review of round goby Neogobius melanostomus biology, spread and ecological implications. J. Fish Biol. 80, 235-285.

Lafrancois, B.M., Riley, S.C., Blehert, D.S., Ballmann, A.E., 2011. Links between type E botulism outbreaks, lake levels, and surface water temperatures in Lake Michigan, 1963-2008. J. Great Lakes Res. 37, 86-91.

Madenjian, C.P., Bunnell, D.B., Desorcie, T.J., Kostich, M.J., Armenio, P.M., Adams, J. V., 2014. Status and trends of prey fish populations in Lake Michigan, 2013. Great Lakes Fishery Commission, Lake Michigan Committee Meeting. 1-15.

Marshall, S., Elliott, M., 1997. A comparison of univariate and multivariate numerical and graphical techniques for determining inter- and intraspecific feeding relationships in estuarine fish. J. Fish Biol. 51, 526-545.

Mosley, C., Bootsma, H., 2015. Phosphorus recycling by profunda quagga mussels (Dreissena rostriformis bugensis) in Lake Michigan. J. Great Lakes Res. 41, 38-48.

Nalepa, T.F., Fanslow, D.L., Lang, G.A., 2009. Transformation of the offshore benthic community in Lake Michigan: recent shift from the native amphipod Diporeia spp. to the invasive mussel Dreissena rostriformis bugensis. Freshwater Biol. 54, 466-479.

Nalepa, T.F., Fanslow, D.L., Pothoven, S.A., 2010. Recent changes in density, biomass, recruitment, size structure, and nutritional state of Dreissena populations in southern Lake Michigan. J. Great Lakes Res. 36, 5-19. 
Nalepa, T.F., Fanslow, D.L., Mabrey, K., Lang, G.A., Rowe, M.D., 2014. Lake-wide benthic surveys in Lake Michigan in 1994-1995, 2002, 2005, and 2010: Abundances of the amphipod Diporeia spp., and abundances and biomass of mussels Dreissena polymorpha and Dreissena rostriformis bugensis. NOAA Technical Memorandum GLERL-1

Needham, J.G., 1900. Insect drift on the shore of Lake Michigan. Occasional Memoirs of the Chicago Entomological Soc. 1, 19-26.

Newman, S.H., Chmura, A., Converse, K., Kilpatrick, A.M., Patel, N., Lammers, E., Daszak, P., 2007. Aquatic bird disease and mortality as an indicator of changing ecosystem health. Mar. Ecol. Prog. Ser. 352, 299-309.

Perez-Fuentetaja, A., Clapsadl, M.D., Getchell, R.G., Bowser, P.R., and Lee, W.T., 2011. Clostridium botulinum type E in Lake Erie: Inter-annual differences and role of benthic invertebrates. J. Great Lakes Res. 37, 238-244.

Peterson, S.R., Ellarson, R.S., 1977. Food habits of oldsquaws wintering on Lake Michigan. Wilson Ornithol. Soc. 89, 81-91.

Piersma, T., 1988. Body size, nutrient reserves and diet of red-necked and Slavonian grebes Podiceps grisegena and P. auritus on Lake Usselmeer, The Netherlands. Bird Study 35, $13-24$.

Pollet, I.L., Shutler, D., Chardine, J., Ryder, J.P., 2012. Ring-billed Gull (Larus delawarensis), The Birds of North America Online (A. Poole, Ed.) [WWW Document]. Birds N. Am. Online. URL http://bna.birds.cornell.edu/bna/species/033

Poste, A.E., Ozersky, T., 2013. Invasive dreissenid mussels and round gobies: A benthic pathway for the trophic transfer of microcystin. Environ. Toxicol. Chem. 32, 2159-2164. Raby, G.D., Gutowsky, L.F.G., Fox, M.G., 2010. Diet composition and consumption 
rate in round goby (Neogobius melanostomus) in its expansion phase in the Trent River, Ontario. Environ. Biol. Fishes 89, 143-150.

Ray, W.J., Corkum, L.D., 1997. Predation of zebra mussels by round gobies, Neogobius melanostomus. Environ. Biol. Fishes 50, 267-273.

Ray, W.J., Corkum, L.D., 2001. Habitat and site affinity of the round goby. J. Great Lakes Res. 27, 329-334.

Reed, T.M., Rocke, T.E., 1992. The role of avian carcasses in botulism epizootics. Wildl. Soc. Bull. 20, 175-182.

Rocke, T.E., Bollinger, T.K., 2007. Avian botulism. In: Thomas, N.J., Hunter, D.B., Atkinson, C.T. (Eds.), Infectious Diseases of Wild Birds. Blackwell Publishing, Ames, Iowa, pp. 377-416.

Roseman, E.F., Schaeffer, J.S., Bright, E., Fielder, D.G., 2014. Angler-caught piscivore diets reflect fish community changes in Lake Huron. Trans. Am. Fish Soc. 143, 1419-1433.

Ross, R.K., Petrie, S.A., Badzinski, S.S., Mullie, A., 2005. Autumn diet of greater scaup, lesser scaup, and long-tailed ducks on eastern Lake Ontario prior to zebra mussel invasion. Wildl. Soc. Bull. 33, 81-91.

Scharf, F.S., Yetter, R.M., Summers, A.P., Juanes, F., 1998. Enhancing diet analyses of piscivorous fishes in the Northwest Atlantic through identification and reconstruction of original prey sizes from ingested remains. Fish. Bull. 96, 575-588.

Seefelt, N.E., Gillingham, J.C., 2006. A comparison of three methods to investigate the diet of breeding double-crested cormorants (Phalacrocorax auritus) in the Beaver Archipelago, northern Lake Michigan. Hydrobiologia 567, 57-67.

Smith, L.D., Sugiyama, H., 1988. Botulism : the organism, its toxins, the disease, 2nd ed, 
American lecture series in clinical microbiology. Springfield, Ill., USA : Thomas, 1988.

Tucker, T., Seefelt, N.E., 2014. Double-crested cormorants (Phalacrocorax auritus) on the move in the Beaver Archipelago, northern Lake Michigan. Waterbirds 37, 99-106.

Tyner, E.H., Bootsma, H.A., Lafrancois, B.M., 2015. Dreissenid metabolism and ecosystemscale effects as revealed by oxygen consumption. J. Great Lakes Res. 41:27-37.

United States Department of the Interior. 1968. Federal Water Pollution Control Administration. 1968. Water pollution problems of Lake Michigan and tributaries. Actions for clean water. U.S. Department of the Interior.

Van Guilder, M.A., Seefelt, N.E., 2013. Double-crested cormorant (Phalacrocorax auritus) chick bioenergetics following round goby (Neogobius melanostomus) invasion and implementation of cormorant population control. J. Great Lakes Res. 39, 153-161.

Walsh, M.G., Dittman, D.E., O’Gorman, R., 2007. Occurrence and food habits of the round goby in the profundal zone of southwestern Lake Ontario. J. Great Lakes Res. 33, 83-92.

Wetmore, A., 1924. Food and economic relations of North American grebes. U.S. Dep. Agric. Dep. Bull. 1196.

Wijesinghe, R.U., Oster, R.J., Haack, S.K., Fogarty, L.R., Tucker, T.R., Riley, S.C., 2015. Spatial, temporal and matrix variability of Clostridium botulinum type E gene (bontE) distribution at beaches in the Great Lakes. Appl. Environ. Microbiol. 81, 4306-4315.

Yule, A.M., Barker, I.K., Austin, J.W., Moccia, R.D., 2006a. Toxicity of Clostridium botulinum type E neurotoxin to Great Lakes fish: implications for avian botulism. J. Wildl. Dis. 42, 479-493.

Yule, A.M., LePage, V., Austin, J.W., Barker, I.K., Moccia, R.D., 2006b. Repeated low level 
exposure of the round goby (Neogobius melanostomas) to Clostridium botulinum type $\mathrm{E}$ neurotoxin. J. Wildl. Dis. 42, 494-500. 


\section{Tables}

Table 1. Collection dates, approximate locations, and sample sizes ( $n$ ) of double-crested cormorants (Phalacrocorax auritus) culled at three locations in northern Lake Michigan. The sex (M, male; F, female) and age class (J, juvenile; A, adult) of most of the birds at each site were also determined.

\begin{tabular}{|c|c|c|c|c|c|c|c|c|}
\hline \multirow[b]{2}{*}{ Location } & \multirow[b]{2}{*}{ Collection Date } & \multirow[b]{2}{*}{ Latitude } & \multirow[b]{2}{*}{ Longitude } & \multirow[b]{2}{*}{$n$} & \multicolumn{2}{|c|}{ Sex } & \multicolumn{2}{|c|}{ Age class } \\
\hline & & & & & M & $\mathrm{F}$ & $\mathrm{J}$ & A \\
\hline Bellow Island (BELL) & 12 June 2012 & 45.10004 & 85.56673 & 11 & 9 & 2 & 2 & 8 \\
\hline Ludington Pump Storage Breakwall (LPSB) & 28 June 2012 & 43.89298 & 86.45562 & 27 & 14 & 5 & 10 & 11 \\
\hline Little and Big Gull Island (GULL) & 24 June 2012 & 45.51412 & 86.71902 & 39 & 21 & 12 & 6 & 27 \\
\hline
\end{tabular}


Table 2. A comparison of percent abundances (proportion of the total number of prey found in gut contents) of prey species consumed by double-crested cormorants (Phalacrocorax auritus) at three sites: Bellow Island (BELL), Little and Big Gull Islands (GULL), and Ludington Pump Storage Breakwall (LPSB), Michigan. Results of Kruskal-Wallis H tests are included in the table ( $p$ values and H). Dunn's post hoc analysis was used to determine which sites differed. Site codes were placed after percent abundances in the table to indicate significant differences among sites.

\begin{tabular}{lcccc}
\hline & BELL & GULL & LPSB & \\
& $n=6$ & $n=31$ & $n=25$ & $p(\mathrm{H})$ \\
\hline Round goby & 50 & 36, LPSB & 62, GULL & $0.02(7.53)$ \\
Alewife & 28 & 42, LPSB & 7, GULL & $<0.01(9.91)$ \\
Dreissenid & 15, LPSB & 18, LPSB & 28, GULL, BELL & $0.02(8.01)$ \\
Yellow perch & 0 & 4 & 2 & $0.23(2.92)$ \\
\hline
\end{tabular}


Table 3. Comparisons of percent abundances (proportion of the total number of prey found in gut contents) of prey items consumed by male and female, and adult and juvenile double-crested cormorants (Phalacrocorax auritus) at three different locations on Lake Michigan: Bellow Island (BELL), Little and Big Gull Islands (GULL), and Ludington Pump Storage Breakwall (LPSB), Michigan. Mann-Whitney U tests were used to identify differences between groups at GULL and LPSB. Sample sizes were too small at BELL to make statistical comparisons. Asterisks indicate significant differences $\left(\begin{array}{lllll}\alpha & < & 0.05\end{array}\right)$ between groups.

\begin{tabular}{|c|c|c|c|c|c|c|c|}
\hline Location & Gut Contents & Male & Female & $p(\mathrm{U})$ & Adult & Juvenile & $p(\mathrm{U})$ \\
\hline \multicolumn{8}{|l|}{ BELL } \\
\hline \multirow[t]{5}{*}{$n$} & & 4 & 2 & & 4 & 1 & \\
\hline & Round goby & 56 & 56 & -- & 34 & 100 & -- \\
\hline & Alewife & 42 & 0 & -- & 42 & 0 & -- \\
\hline & Dreissenid & 2 & 44 & -- & 24 & 0 & -- \\
\hline & Yellow perch & 0 & 0 & -- & 0 & 0 & -- \\
\hline \multicolumn{8}{|l|}{ GULL } \\
\hline \multirow[t]{5}{*}{$n$} & & 16 & 10 & & 21 & 5 & \\
\hline & Round goby & 29 & 67 & $0.10(112)$ & 38 & 51 & $0.40(39)$ \\
\hline & Alewife & 41 & 25 & $0.85(76)$ & 42 & 13 & $0.06(81)$ \\
\hline & Dreissenid & 24 & 3 & $0.02(37) *$ & 16 & 25 & $0.08(26)$ \\
\hline & Yellow perch & 6 & 5 & $0.93(82)$ & 4 & 11 & $0.13(32)$ \\
\hline \multicolumn{8}{|l|}{ LPSB } \\
\hline \multirow[t]{5}{*}{$n$} & & 13 & 5 & & 11 & 10 & \\
\hline & Round goby & 66 & 56 & $0.30(22)$ & 52 & 71 & $0.02(22) *$ \\
\hline & Alewife & 4 & 14 & $0.90(31)$ & 13 & 1 & $0.31(67)$ \\
\hline & Dreissenid & 27 & 29 & $0.92(34)$ & 31 & 25 & $0.36(69)$ \\
\hline & Yellow perch & 3 & 1 & $0.82(30)$ & 2 & 3 & $0.81(59)$ \\
\hline
\end{tabular}


Table 4. Size ranges and grand mean total lengths (TL) of the three most common prey fish found in the gut contents of BoNT-free double-crested cormorants collected from three different locations in Lake Michigan: Bellow Island (BELL), Little and Big Gull Islands (GULL), and Ludington Pump Storage Breakwall (LPSB), Michigan.

\begin{tabular}{ccccccc}
\hline & \multicolumn{2}{c}{ Round Goby } & \multicolumn{2}{c}{ Alewife } & \multicolumn{2}{c}{ Yellow Perch } \\
Location & $\begin{array}{c}\text { Size Range } \\
(\mathrm{mm})\end{array}$ & $\begin{array}{c}\text { Grand Mean } \\
\text { TL }(\mathrm{mm})\end{array}$ & $\begin{array}{c}\text { Size Range } \\
(\mathrm{mm})\end{array}$ & $\begin{array}{c}\text { Grand Mean } \\
\text { TL }(\mathrm{mm})\end{array}$ & $\begin{array}{c}\text { Size Range } \\
(\mathrm{mm})\end{array}$ & $\begin{array}{c}\text { Grand Mean } \\
\text { TL }(\mathrm{mm})\end{array}$ \\
\hline BELL & $40-226$ & $119 \pm 19$ & $98-142$ & $117 \pm 7$ & -- & -- \\
GULL & $33-218$ & $91 \pm 6$ & $20-162$ & $104 \pm 5$ & $45-146$ & $95 \pm 9$ \\
LPSB & $37-172$ & $105 \pm 4$ & $39-148$ & $114 \pm 13$ & $79-143$ & $112 \pm 7$ \\
\hline
\end{tabular}

\section{Figure Captions}

Figure 1. Locations where sick or dead waterbirds (circles) were collected in three areas on northern Lake Michigan: Door County and neighboring counties (DOOR), eastern Upper Peninsula of Michigan (EUP), and Sleeping Bear Dunes National Lakeshore, Michigan (SLBE). Culled cormorants were collected at Bellow Island (BELL), Little and Big Gull Island (GULL), and the Ludington Pump Storage Breakwall (LPSB).

Figure 2. Modified Costello graphs that show the importance of different prey items in the gut contents of birds based on mean percent abundance (proportion of the total number of prey found in gut contents) in the diet and frequency of occurrence (proportion of birds containing the prey item). Prey items depicted in the graphs include round gobies (Neogobius melanostomus; RG), dreissenid mussels (DR), alewives (Alosa pseudoharengus; AL), yellow perch (Perca flavescens; YP), crayfish (CR), chironomids (CH), terrestrial insects (TI), and gastropods (GA). Prey that composed $<1 \%$ of the total prey consumed by a species, or that were considered incidentally 
consumed, were excluded. When birds that tested negative for botulinum neurotoxin type E were examined they were represented separately.

Figure 3. A comparison of the size class distribution of round gobies (Neogobius melanostomus) consumed by fish-eating birds collected in Lake Michigan from 2010 to 2012. The bars show mean proportions $( \pm$ S. E.) of round gobies in each size class. The number of individual birds sampled that contained intact dentary bones, which were used to back-calculate round goby length, is included on the top right of each graph. One red-necked grebe contained round gobies, so standard errors were not calculated. Except for 3 of 19 ring-billed gulls and 12 of 30 common loons, all birds represented tested positive for botulinum neurotoxin type E (BoNT/E). There was no difference between the size-class distributions found in BoNT/E-positive and -negative common loons $(\mathrm{G}[\mathrm{df}=4]=3.79, p=0.43)$, thus data were pooled. Small sample sizes precluded statistical comparisons, but visual inspection of the data suggested that there was little difference between the size-class distributions of round gobies in BoNT/E-positive and -negative ring-billed gulls, so data were pooled.

Figure 4. Modified Costello graphs that show the importance of round gobies (Neogobius melanostomus; RG), alewives (Alosa pseudoharengus; AL), yellow perch (Perca flavescens; YP), and dreissenid mussels (DR) consumed by botulism-free, double-crested cormorants (Phalacrocorax auritus) grouped by age class (adults and juveniles) and sex (male and female). Sample sizes $(n)$ are displayed. All birds were collected from breeding colonies in Lake Michigan during summer 2012, and importance of each prey item is based on mean proportion of gut contents (proportion of the total number of prey found in gut contents) and frequency of occurrence (proportion of birds that consumed the prey item). 


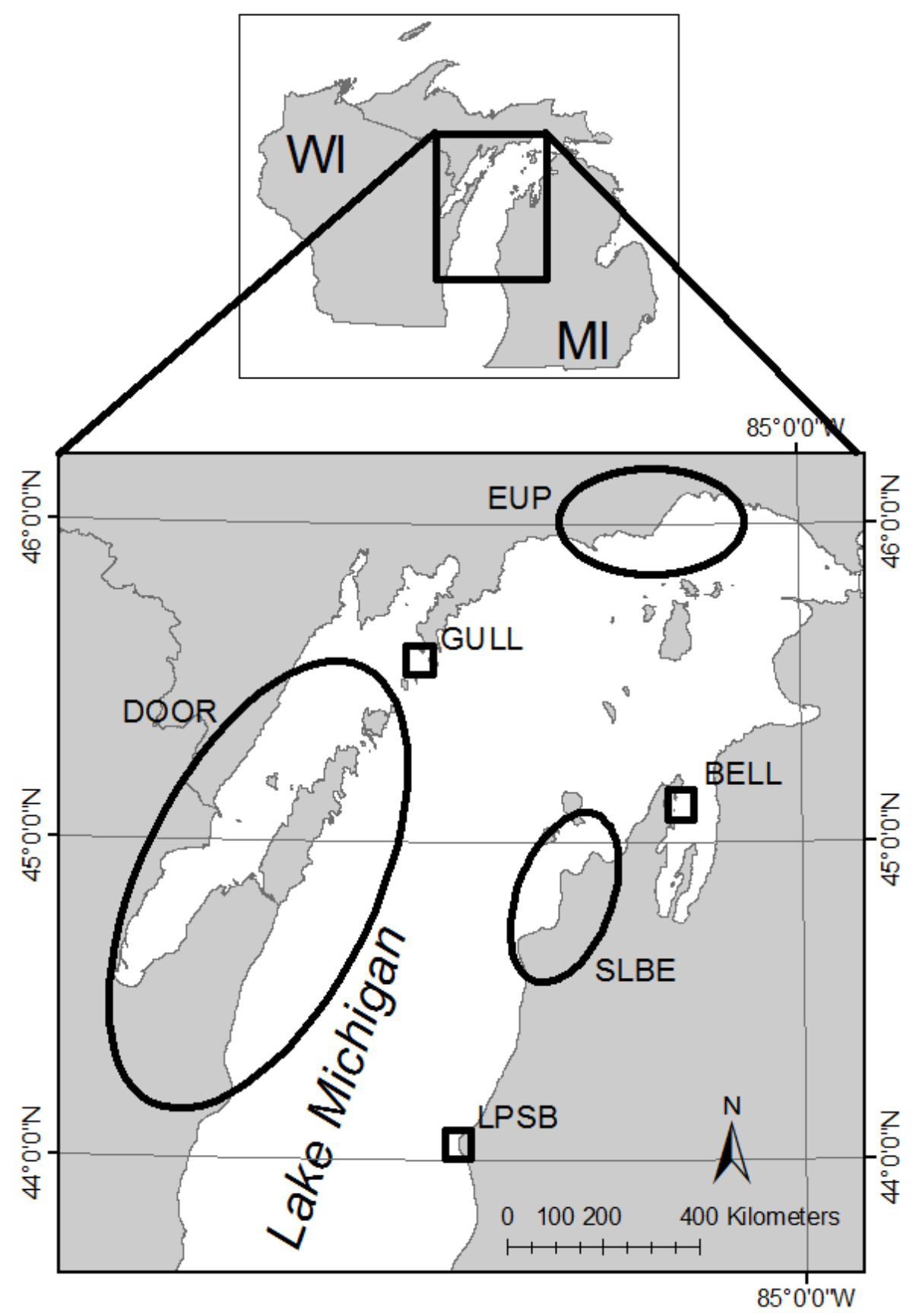




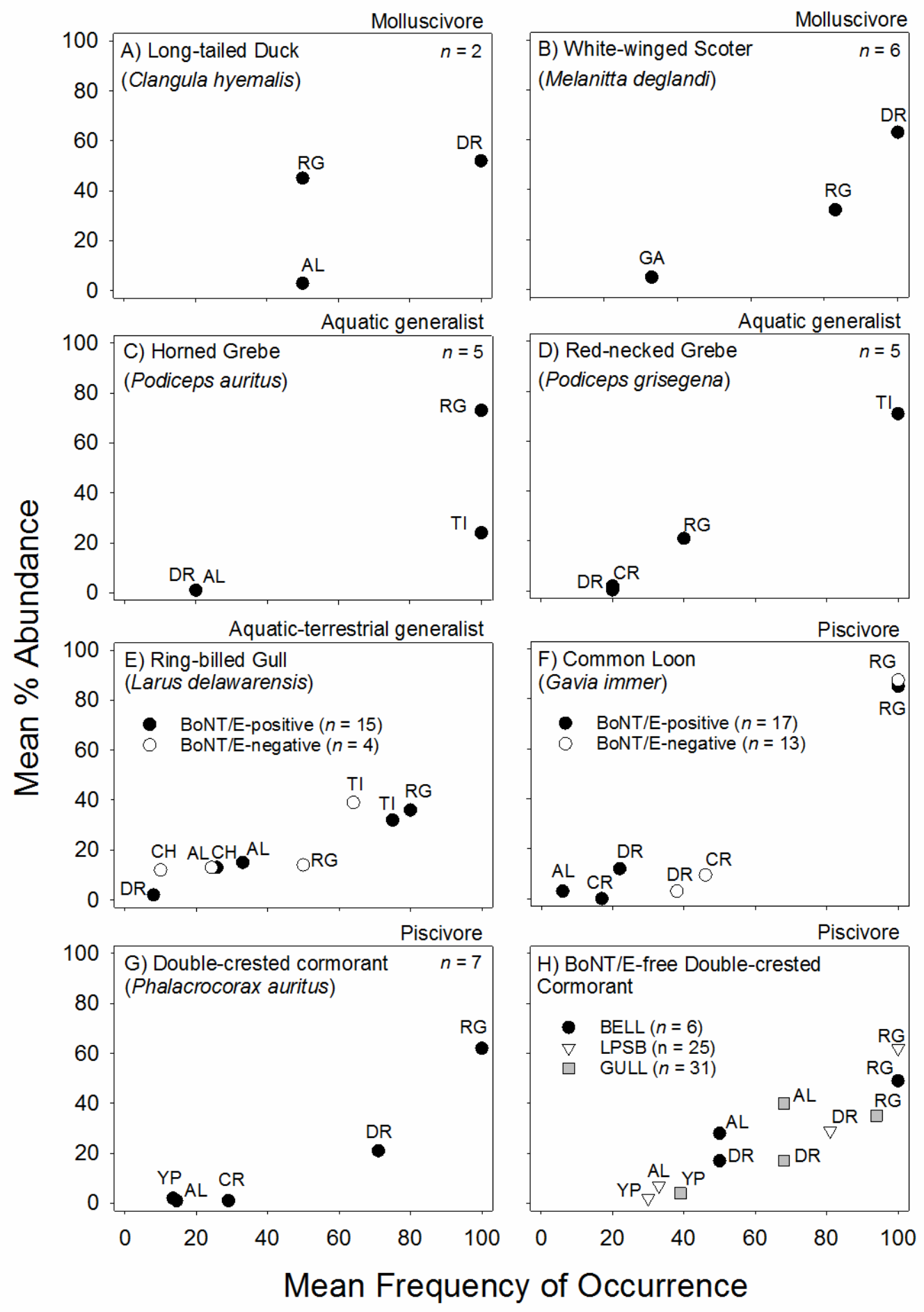




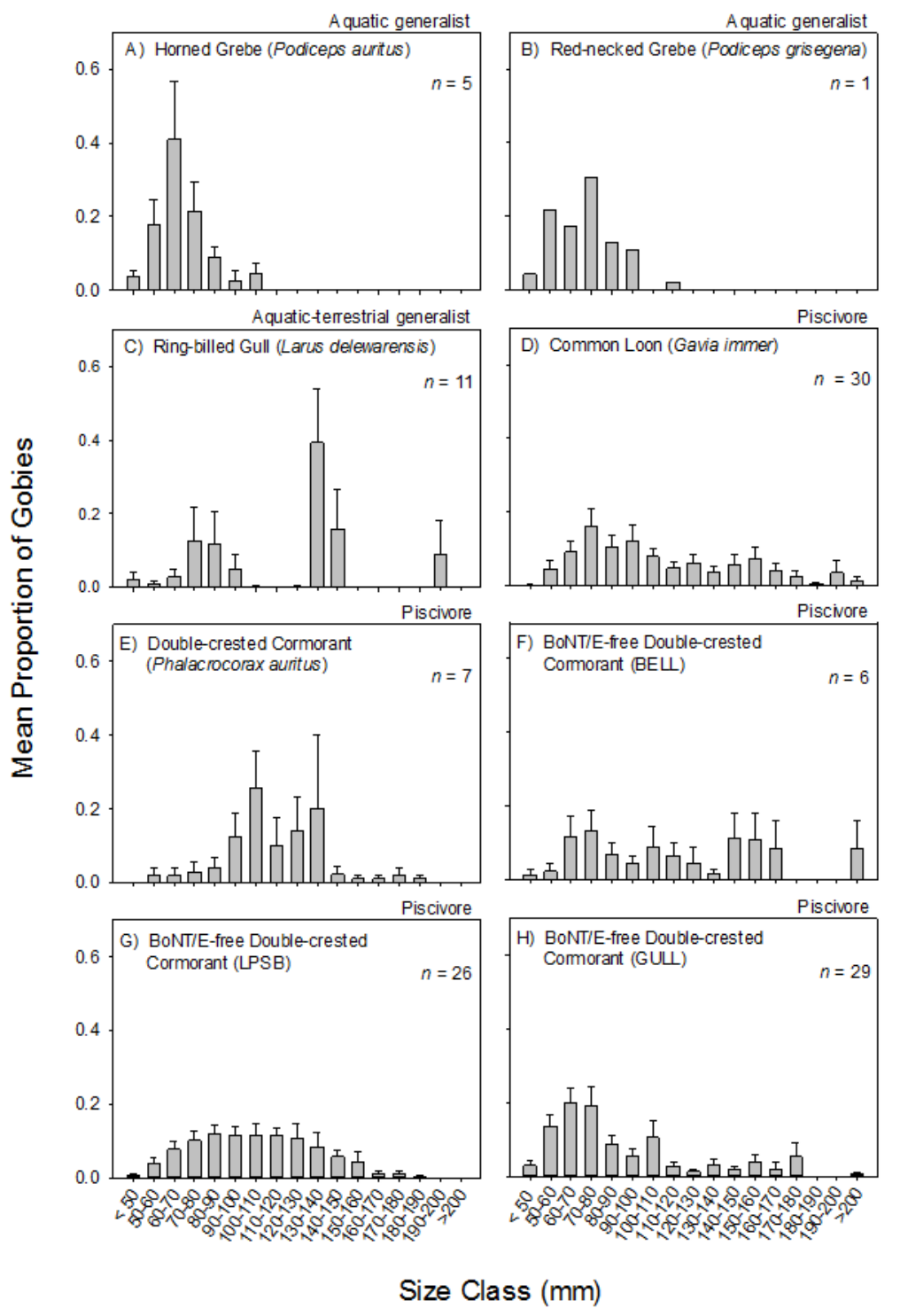




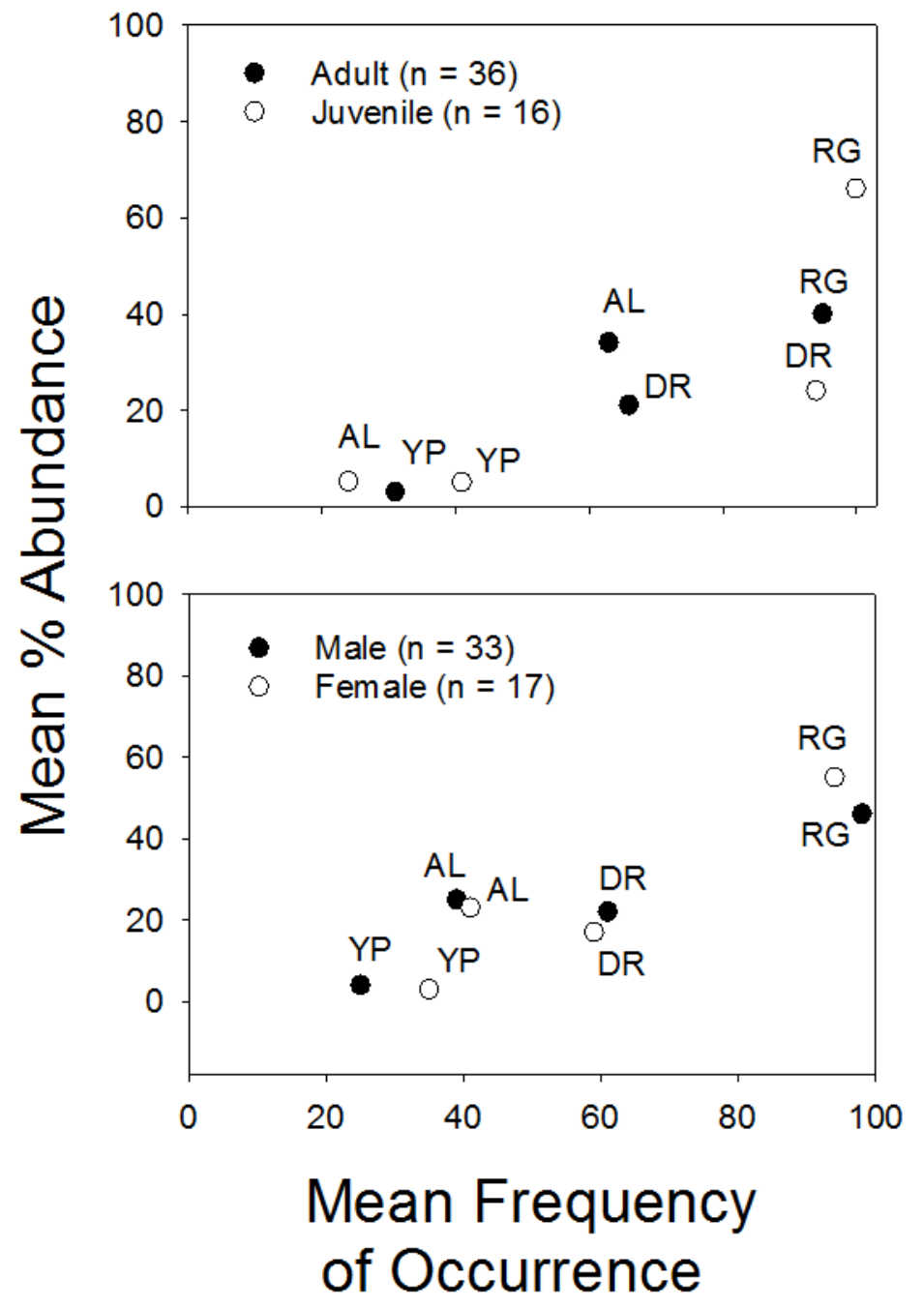

